\title{
ANALISIS PENGARUH EDMODO TERHADAP MINAT BELAJAR SISWA SMP PADA MATERI GETARAN, GELOMBANG DAN BUNYI
}

\author{
Chusnul Chotimah ${ }^{1}$, Anjar Putro Utomo ${ }^{2}$, Sri Wahyuni ${ }^{3}$ \\ ${ }^{123}$ Fakultas Keguruan dan Ilmu Pendidikan, Universitas Jember \\ e-mail: chusnulchotimah735@gmail.com
}

\begin{abstract}
ABSTRAK
Tujuan dalam penelitian ini adalah untuk mengetahui pengaruh edmodo terhadap minat belajar siswa. Jenis penelitian yaitu penelitian eksperimen dengan rancangan Quasi Eksperiment. Desain yang digunakan yaitu Nonequivalent Control Group Design. Metode pengumpulan data menggunakan angket minat belajar siswa dengan menggunakan 4 indikator yaitu perasaan senang, perhatian siswa, keterlibatan siswa dan ketertarikan siswa. Data akan dianalisis menggunakan N-Gain. Berdasarkan hasil analisis minat belajar siswa mengalami peningkatan sebesar $42 \%$ pada kelas eksperimen dengan pembelajaran menggunakan edmodo. Sehingga dapat disimpulkan bahwa pembelajaran menggunakan edmodo dapat berpengaruh terhadap minat belajar siswa.
\end{abstract}

Kata Kunci: Edmodo, Minat Belajar, Siswa, Getaran

\section{ABSTRACT}

The purpose of this study was to determine the effect of Edmodo on student interest in learning. This type of research is experimental research with a Quasi Experiment design. The design used is Nonequivalent Control Group Design. The data collection method used a questionnaire of student learning interest using 4 indicators, namely feelings of pleasure, student attention, student involvement and student interest. The data will be analyzed using $\mathrm{N}$-Gain. Based on the results of the analysis of student interest in learning has increased by $42 \%$ in the experimental class with learning using edmodo. So it can be concluded that learning using edmodo can affect student interest in learning.

Keywords: Edmodo, Interest in Learning, Students, Vibration

\section{PENDAHULUAN}

Pendidikan merupakan salah satu sarana untuk mencerdaskan kehidupan bangsa, mencetak sumber daya manusia yang berkualitas. Melalui pendidikan manusia bisa memperluas wawasannya serta memperoleh ilmu pengetahuan. Salah satunya yaitu ilmu pengetahuan alam. Ilmu Pengetahuan Alam merupakan suatu proses penemuan dan penguasaan pengetahuan yang berupa konsep, fakta serta prinsip. IPA adalah ilmu yang membahas tentang fakta dan gejala alam dan bersifat empirik (Ejin, 2016). Banyak permasalahan yang sering muncul pada pembelajaran IPA, diantaranya adalah mata 
pelajaran IPA materi getaran, gelombang dan bunyi yang merupakan materi yang abstrak sehingga kurangnya siswa memahami materi akan mengakibatkan menurunnya minat belajar siswa, yang terutama disebabkan oleh rasa bosan dan kurang berpartisipasi aktif dalam pembelajaran (Awalsyah, 2018).

Dalam proses pembelajaran sangatlah penting memacu minat belajar siswa (Siriat, 2016). Karena minat belajar sangat berpengaruh positif terhadap pembelajaran akademik, domain pengetahuan dan bidang studi bagi individu (Nurhasanah, 2016). Minat akan mempengaruhi kualitas hasil belajar siswa pada bidang studi yang diminatinya. Minat belajar yang besar seringkali mengarah pada prestasi belajar yang tinggi, sedangkan minat belajar yang rendah menyebabkan prestasi belajar yang rendah (Slameto, 2015). Berdasarkan penelitian yang telah dilakukan oleh Yunita (2015) mengatakan bahwa faktorfaktor yang mempengaruhi kurangnya minat belajar siswa antara lain siswa kurang berminat pada mata pelajaran IPA, pemahaman terhadap materi IPA masih rendah, karena penyampaian materi yang monoton, guru kurang menggunakan media menarik saat proses pembelajara. Pembelajaran yang menarik dan efektif memerlukan bantuan media yang menunjang proses pembelajaran, agar siswa senang saat mengikuti proses pembelajaran dan dapat dengan mudah memperoleh ilmu yang diberikan oleh guru (Asrofi, 2008).

Pemilihan media yang mendukung sangat penting untuk digunakan dalam proses pembelajaran sebagai sarana dalam menyampaikan sebuah materi pelajaran sehingga dapat menghindari siswa dari rasa bosan (Annisa, 2018). Media pembelajaran adalah alat bantu guru pada saat mengajar untuk menyampaikan materi pengajaran, meningkatkan kreatifitas dan perhatian siswa dalam proses pembelajaran dan juga dapat membuat proses pembelajaran menjadi lebih mearik dan menyenangkan (Tafonao, 2018).

Media pembelajaran untuk saat ini sangatlah banyak khususnya pada dunia teknologi informasi dan komunikasi (TIK), hal ini mempengaruhi transformasi pendidikan konvensional ke dalam bentuk pendidikan berbasis digital yang sering disebut dengan elearning. Salah satu bentuk media pembelajaran yang berbasis e-learning adalah edmodo (Jumaeroh, 2019:119). Edmodo merupakan sebuah portal informasi disajikan dengan tampilan yang menarik dan cocok untuk menumbuhkan minat belajar siswa. Edmodo memberi kemudahan untuk guru dan siswa sebagai tempat yang aman untuk kolaborasi, komunikasi, pemberian konten, forum diskusi, tes online, evaluasi (Muhajir et al, 2019).

Edmodo memiliki tampilan sederhana yang seperti facebook, sehingga memudahkan siswa untuk belajar mandiri, kolaborasi dan interaksi guru dengan siswa yang akan mengugah keceriaan dan semangat siswa dalam belajar (Rismayanti, 2013). Penelitian sebelumnnya yang dilakukan menggunakan edmodo menunjukkan bahwa edmodo dapat membuat siswa lebih terlibat dalam proses pembelajaran. Edmodo adalah alat yang perlu untuk dikenalkan kepada siswa, karena dengan menggunakan edmodo mempermudahan untuk berinteraksi dalam dunia pendidikan dan lebih produktif (Bruce, 2013).

Edmodo yang dihadirkan dalam konsep gamifikasi dapat mendorong rasa senang dan partisipasi siswa dalam proses pembelajaran (Jusuf, 2016). Pembelajaran dengan menggunakan edmodo sebagai strategi pembelajaran alternatif untuk memberdayakan siswa yang merupakan konsep pembelajaran yang dapat membantu guru menghubungkan materi pembelajaran, tugas mandiri dan terstruktur. Dengan konsep pembelajarn seperti ini 
diharapkan pembelajaran bermakna dan dapat meningkatkan minat belajar siswa (Hidayat, 2019). Berdasarkan uraian di atas, maka tujuan penelitian ini adalah untuk mengetahui pengaruh edmodo terhadap minat belajar siswa.

\section{METODE}

Jenis penelitian ini adalah penelitian eksperimen. Rancangan yang digunakan yaitu Quasi Eksperiment dengan desain penelitian yang digunakan adalah Nonequivalent Control Group Design. Penelitian ini menggunakan dua kelas, satu kelas bertindak menjadi kelas eksperimen dan kelas lain bertindak menjadi kelas kontrol. Kelas eksperimen merupakan kelompok yang diberikan perlakuan (X) yaitu pembelajaran dengan edmodo. Kelas diberikan pretest dan posttest kemudian hasilnya akan dianalisis untuk mengetahui pengaruh terhadap minat belajar siswa di kelas.

\begin{tabular}{lllll}
\multicolumn{5}{c}{ Tabel 1. Desain Penelitian } \\
\hline & Kelas & Prettest & Perlakuan & Posttest \\
\hline $\mathrm{R}_{1}$ & Eksperimen & $\mathrm{T}_{1}$ & $\mathrm{X}$ & $\mathrm{T}_{2}$ \\
\hline $\mathrm{R}_{2}$ & Kontrol & $\mathrm{T}_{3}$ & - & $\mathrm{T}_{4}$ \\
\hline
\end{tabular}

Desain penelitian Nonequivalent Control Group Design (Creswell, 2018)

Keterangan :

$\mathrm{R}_{1}=$ Kelas eksperimen

$\mathrm{R}_{2}=$ Kelas kontrol

$\mathrm{T}_{1}=$ prettest pada kelas perlakuan

$\mathrm{T}_{3}=$ prettest pada kelas perlakuan

$\mathrm{X}=$ Proses pembelajaran dengan media edmodo

-= Proses pembelajaran tanpa media edmodo

$\mathrm{T}_{2}=$ Hasil posttest kelas eksperimen

$\mathrm{T}_{4}=$ Hasil posttest kelas kontrol

Penelitian ini dilaksanakan di MTs Negeri 8 Banyuwangi pada semester genap tahun ajaran 2020/2021. Metode pengumpulan data dilakukan dengan menggunakan angket minat belajar siswa dengan menggunakan 4 indikator yaitu perasaan senang, perhatian siswa, keterlibatan siswa dan ketertarikan siswa. Kemudian data akan dianalisis dengan langkah sebagai berikut :

\section{Menentukan nilai minat belajar siswa}

Untuk mengetahui nilai yang diperoleh oleh siswa, maka skor diubah ke nilai dengan rumus sebagai barikut (Arlini et al., 2017):

$$
\text { Nilai }=\frac{\text { skor yang diperoleh siswa }}{\text { skor maksimum }} \times 100
$$

\section{N-Gain}

N-Gain digunakan untuk mengetahui peningkatan yang terjadi pada minat belajar siswa. Perhitungan N-Gain dapat menggunakan persamaan berikut :

$$
<\mathrm{g}>=\frac{\%<S_{f}>-\%<S_{i}>}{\%<S_{\text {maks }}>-\%<S_{i}>} \times 100 \%
$$


Dengan

$\mathrm{S}_{\mathrm{f}}=$ skor final (posttest)

$\mathrm{S}_{\mathrm{i}}=$ skor initial (pretest)

$\mathrm{S}_{\text {maks }}=$ skor masimum yang mungkin dicapai

(Hage, 1999).

\section{HASIL DAN PEMBAHASAN}

Penelitian ini bertujuan untuk mengetahui pengaruh edmodo terhadap minat belajar siswa. Berdasarkan nilai yang telah diperoleh yaitu nilai minat awal siswa (pretest) dan nilai minat akhir siswa (posttest), maka melakukan presentase N-Gain. Data presentase NGain dapat dilihat pada tabel 2.

Tabel 2. Hasil presentase N-Gain minat belajar siswa

\begin{tabular}{|l|c|c|}
\hline Indikator & Kelas Kontrol & Kelas Eksperimen \\
\hline Perasaan senang & $16 \%$ & $36 \%$ \\
\hline Perhatian siswa & $1 \%$ & $63 \%$ \\
\hline Keterlibatan siswa & $7 \%$ & $30 \%$ \\
\hline Ketertarikan siswa & $4 \%$ & $40 \%$ \\
\hline Rata-rata keseluruhan siswa & $6 \%$ & $42 \%$ \\
\hline
\end{tabular}

Berdasarkan tabel 2 menunjukkan bahwa presentase peningkatan nilai minat belajar siswa pada kelas kontrol tertinggi pada indikator perasaan senang siswa sebesar $16 \%$ dan presentase peningkatan terendah pada indiator perhatian siswa sebesar $1 \%$. Sedangkan presentase peningkatan rata-rata minat belajar siswa sebesar 6\%. Pada kelas eksperimen presentase peningkatan nilai minat belajar terendah pada indikator keterlibatan siswa sebesar 30\% dan presentase peningkatan tertinggi pada indikator perhatian siswa sebesar $63 \%$. Sedangkan presentase peningkatan rata-rata minat belajar siswa sebesar $42 \%$. Yang menunjukkan bahwa rata-rata minat belajar setiap siswa dengan pembelajaran menggunakan edmodo dapat meningkat kemungkinan $42 \%$ dalam tiga kali pertemuan. Presentase peningkatan minat belajar siswa kelas eksperimen lebih besar dibandingkan kelas kontrol. Hal tersebut karena pada kelas eksperimen pembelajaran menggunakan edmodo, dimana edmodo berisian fitur-fitur yang mendukung dapat merangsang semangat, perasaan senang dan semangat siswa selama proses pembelajaran (Darmawan, 2014).

Menurut Anggraini (2019) menyatakan bahwa siswa menganggap pembelajaran dengan menggunaan edmodo adalah pembelajaran yang mudah dan menarik, dimana hal tersebut didapatkan dari hasil wawancara bahwa siswa tidak mengalami kesulitas dalam penggunaan edmodo hal tersebut karena tampilan dari edmodo mirip dengan facebook sehingga siswa tertarik untuk memperhatikan apa yang telah dipelajari. Minat belajar merupakan salah satu alasan seorang siswa untuk mengambil suatu tindakan. Minat belajar akan menunjukkan keinginan untuk mengembangkan ketrampilan, mencari informasi dan mampu menguasai ilmu tersebut. Minat siswa dalam menggunakan perangkat lunak lebih besar dibandingkan minat belajar konvensional dikelas. Pembelajaran menggunakan edmodo untuk mewujudkan potensi teknologi memberikan pengaruh positif bagi siswa (Vania, 2018). 
Berdasarkan hasil penelitian menunjukkan bahwa penggunaan edmodo dalam pembelajaran dapat berdampak positif terhadap minat belajar siswa, dimana semakin menarik alat bantu yang digunakan dalam pembelajaran maka semakin besar minat siswa dalam proses pembelajaran. Hasil penelitian ini di dukung oleh penelitian Muhajir (2019) bahwa pembelajaran menggunakan edmodo sangat baik, dengan skor rata-rata minat belajar siswa sebesar 347,6 dan persentase sebesar $81,25 \%$. Siswa sangat senang, tertarik dan minat mengiuti pembelajaran menggunakan edmodo dengan tampilannya yang memudahkan siswa dalam memahami materi pembelajaran sehingga meningatkan minat belajar siswa. Menurut Fauziyah (2020) bahwa pembelajaran menggunakan edmodo menarik, daya tarik tersebut karena terdapat berbagai ativitas yang dilakukan selama pembelajaran seperti mengunggah PR, mengerjakan kuisioner online, berdiskusi pada forum diskusi, memberikan pertanyaan diluar pembelajaran.

Kegiatan pembelajaran yang dapat dikatakan terlaksana dengan baik yaitu yang mendapat respon dan diterima dengan baik dari siswa. Hasil penelitian Mumaridah (2018) menunjukkan bahwa pembelajaran dengan edmodo dapat mempengaruhi minat belajar siswa dengan hasil yang diperoleh yaitu persentase $54 \%$ yang memiliki kriteria sangat menarik dan $46 \%$ memiliki kriteria tertarik. Sedangkan persentase rata-rata minat belajar siswa sebesar 85,63\%. Penelitian yang dilakukan oleh Supriyadi (2014) menunjukkan bahwa penggunaan edmodo untuk pembelajaran dapat membuat perubahan yang lebih baik dalam aktivitas, motivasi dan minat belajar siswa antara lain semangat belajar yang berpusat pada siswa, rasa tanggung jawab siswa dalam mengerjakan tugas dan semangat kerja tim.

\section{PENUTUP}

Berdasarkan hasil penelitian dan diskusi, dapat disimpulkan bahwa pembelajaran dengan menggunakan edmodo dapat berpengaruh terhadap minat belajar siswa, dimana dilihat dari peningkatan minat belajar siswa sebesar $42 \%$.

\section{UCAPAN TERIMA KASIH}

Terimakasih kepada Dosen Pembimbing yang telah membimbing untuk menyelesaikan artikel ini dan juga terimakasih kepada Kepala Sekolah dan Guru Pamong yang telah berkenan membantu serta memberi arahan sehingga penelitian ini berjalan dengan baik.

\section{DAFTAR PUSTAKA}

Awalsyah, A., S. Sarwi, dan S. Sutikno. 2018. Pengembangan Lembar Kerja Siswa (Lks)

Berbantuan Kvisoft Flipbook Maker Untuk Mengembangkan Keterampilan Ilmiah Siswa. Upej Unnes Physics Education Journal.7(3):28-35.

Annisa, Nurul. 2018. Pengembangan Media Pembelajaran Interaktif IPA Berbasis Model

Pembelajaran Guided Inquiry Pada Materi Gaya Di Kelas IV SD Negeri 101776 Sampali. School Education Journal. 8(2):217-229.

Arlini, H., N. Humairah, dan D. Sartika. 2017. Penerapan Model Pembelajaran Kooperatif

Tipe Think Pair Share Dengan Teknik Advance Organizer. Saintifik. 3(2):182-189.

Asrofi, M. 2008. E-Learning Konsep dan Aplikasi. Yogyakarta: Andi Yogyakarta. 
Bruce, K. G. 2013. How Edmodo into a High School Service Club: To Promote Interactive Online Communication. USA: 18 Th TCC Worldwide Online Conference.

Creswell, John W. 2018. Qualitative, Quantitative, and Mixed Approaches Fifth Edition. California:Sage Publishing.

Darmawan, D. 2014. Pengembangan E-Learning Teori dan Desain. Bandung:PT Remaja Rosdakarya.

Ejin, Syahroni. 2016. Pengaruh Model Probem Based Learning (PBL) terhadap Pemahaan

Konsep Dan Keterampilan Berfikir Kritis Siswa Kelas IV SDN Jabu Hilir Baluti 2 Pada Mata Pelajaran Ilmu Pengetahuan Alam. Jurnal Pendidikan. 1(1):65-71.

Fauziyah, S., dan M. B. Triyono. 2020. Pengaruh E-Learning Edmodo Dengan Model Blended Learning Terhadap Minat Belajar. Jurnal Pendidikan. 4(1):112-124.

Hake, R. R. 1999. Interactive-engagement versus traditional methods: A six-thousandstudent survey of mechanics test data for introductory physics courses. American Journal of Physics. 66(1): 64-74.

Hidayat, P. W., dan Abdulah. 2019. Pengaruh Pembelajaran E-Learning Berbasis Edmodo

Terhadap Minat Dan Hasil Belajar Mahasiswa Pgsd Stkip Muhammadiyah Muara Bungo. Jurnal Pendidikan Matematika. 3(1):104-115.

Jumaeroh, Siti. 2019. Pengaruh Media Edmodo Terhadap Hasil Belajar IPA pada Tekanan dengan Model Discovery Learning. Jurnal Thabiea. 2(2):118-122.

Jusuf, H. 2016. Penggunaan Gamifikasi dalam Proses Pembelajaran. Jurnal TICOM. 5(1): $1-10$.

Muhajir., R. Musfikar, dan Hazrullah. 2019. Efektivitas Penggunaan E-Learning Berbasis Edmodo Terhadap Minat Dan Hasil Belajar (Studi Kasus Di Smk Negeri Al Mubarkeya). Jurnal Pendidikan Teknologi Informasi. 3(1):50-56.

Mumaridah, E., A. B. Santoso, Sriyono, dan E. Suharini. 2018. Efektivitas Penggunaan Model Pembelajaran Blended Learning berbasis edmodo pada Mata Pelajaran Geografi Materi Mitigasi Dan Adaptasi Bencana Alam Kelas X Sma N 2 Sukorejo Kabupaten Kendal Tahun Ajaran 2017-208. Proceeding SNK-PPM. 1(2):179-184.

Rismayanti, A. 2013. Materi Simulasi Digital: Where Learning Happens. South Asian Ministers of Education Organization Regional Open Learning

Sirait, E. D. 2016. Pengaruh Minat Belajar Terhadap Prestasi Belajar Matematika. Formatif: Jurnal Ilmiah Pendidikan MIPA. 6(1):35-43.

Slameto. 2015. Belajar \& Faktor-faktor Yang Mempengaruhi. Jakarta: PT Rineka Cipta

Supriyadi. 2014. "Pemanfaatan ICT Social Network Edmodo Untuk Meningkatkan Aktivitas dan Motivasi Belajar Listrik Dinasmis Dalam Pembelajaran Jarak Jauh (Kelas XI TKR 1 Program T-Tep SMKN 1 Cirebon”, Tesis Pascasarjana Prodi Pendidikan Sains UNS. Surakarta.

Tafonao, Talizaro. 2018. Peranan Media Pembelajaran Dalam Meningkatkan Minat Belajar Mahasiswa. Jurnal Komunikasi Pendidikan. 2(2):103-114.

Vania, P. F., W. Setiawan, A. Fany, dan C. Wijaya. 2018. Edmodo as Web-Based Learning to Improve Student 's Cognitive and Motivation in Learning Thermal Physics. Journal of Science Learning. 1(3):110-115.

Yunita, R., R. Lestari, dan E. M. Brahmana. 2015. Minat Belajar Siswa Kelas VIII Terhadap Mata Pelajaran IPA DI Mts PP Hasanatul Barokah Tambusai Timur Tahun 
Pembelajaran 2014/2015. Artikel Program Studi Pendidikan Biologi FKIP Universitas Pasir Pengarain. 